\title{
Selected Clauses of a Copyright Contract in Polish and English in Translation by Google Translate: A Tentative Assessment of Quality
}

\section{Paula Trzaskawka ${ }^{1}$ (D)}

Published online: 24 January 2020

(c) The Author(s) 2020

\begin{abstract}
The aim of this paper is to carry out a comparative analysis of clauses in Polish and English copyright agreements in respect of their translation by a computer assisted tool-Google Translate, and to assess the quality of such translation. The comparison of parallel texts as a research method has been applied. The research corpora include authentic Polish and English Copyright Agreements. The analysed clauses have been excerpted from the above mentioned Copyright Agreements. The author chose the most standard clauses as well as clauses typical for copyright contracts. As a result of the analysis, translations provided by Google Translate are better in terms of typical clauses but of worse quality in terms of specialised copyright clauses.
\end{abstract}

Keywords Contract clauses · Copyright contract · Translation · Google Translate · Assessment

\section{Introduction}

A translation made by a person with the usage of a computer, or a translation using only a computer is an increasingly popular topic among researchers and translation practitioners. It is said (see Kubacki and Łomzik [21: 1]) in the last 20 years of the twenty-first century that computer translation, thanks to the development of new technologies, has been refined to such an extent that the quality is satisfactory, especially for the needs of specialist translation. But it is disputable in some cases (e.g. [26]) compared the language of hunters in terms of the traditional translations versus Google Translate translations. It appeared that there were many cases of mistranslations concerning Google Translate.

Paula Trzaskawka

paula.trzaskawka@amu.edu.pl

1 Adam Mickiewicz University in Poznan, Poznan, Poland 
According to Kubacki and Łomzik [21: 1], machine translation generates a machine, i.e. a computer that replaces a human being in the process of translation. An example of such a translating machine is Google Translate. Nowadays, more and more translators are using computer-assisted translations which are performed by a translator while using various computer software (cf. [8]).

In this article, the selected clauses excerpted from the Polish and English copyright agreements will be discussed. The analysis concerns conventional clauses as well as those which are specific for copyrights. Moreover, it should be stressed that the topic of copyrights is worldwide in nature. Google Translate, is one example of the rapid development of technological devices such as translation tools.

The aim of the study is to analyze Polish and English selected clauses from copyright transfer agreements in respect to revealing the quality of Google Translate translation. The following research method has been applied:

(1) comparison of parallel texts (cf. [6, 16, 22, 25, 28, 31]);

(2) the analysis and comparison of comparable texts (cf. [6, 16, 22, 28, 31]).

The research corpora includes:

(1) Authentic Polish and English Copyright Transfer Agreements.

As a result of the analysis, translations provided by Google Translate will be presented in tables together with the proper translation made by the author. Each example of a clause from a table is going to be discussed and analyzed in terms of the quality of the machine aided translation.

\section{Google Translate as a Machine Translation}

Google Translate is a free multilingual machine translation service developed by Google LLC, to translate text. It was launched in April 2006 as a statistical machine translation service. At the beginning rather than translating languages directly, it first translated text to English and then to the target language. In November 2016, Google announced that Google Translate would switch to a neural machine translation engine - Google Neural Machine Translation (GNMT) (cf. [27])—which translates "whole sentences at a time, rather than just piece by piece. It uses this broader context to help it figure out the most relevant translation, which it then rearranges and adjusts to be more like a human speaking with proper grammar". ${ }^{1}$

When it comes to the way translations and additional options work, Google Translate recognizes the language of the source text in combinations of over 100 languages. The source text is pasted or typed into the window and the program automatically "spits out" the translation.

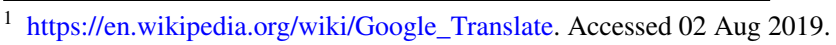


However, by using the program, we have to prepare for some of its limitations. The length of the texts cannot exceed 5000 characters with spaces. Nevertheless, in the case of the analysis of short contractual clauses as in this article, this limitation does not constitute an obstacle. Also, the system maintains the style of the source text (font, font size, bold, italic type) because when the text is pasted into a window, it is automatically formatted.

\section{Research Results}

\subsection{An Attempt to Assess the Quality of Google Translate Translation}

Of the research conducted on Google Translate assessed by practicing translators most were in English. On the blog written by Polish author Katarzyna Lwowska ${ }^{2}$ it is stated that Google Translate is not for professional translation. This program only helps with communication. Even though the application works fast and translates not only particular words but whole sentences and texts, it makes many mistakes (grammatical, stylistic and lexical) and it has problems with translating more complex sentences. All in all, it is said that the poor quality of translation by Google Translate is visible in Asian languages, e.g. Japanese or Arabic (cf. [19]). Nonetheless, Aiken [1] shows in his study, that Google Translate since 2011 has improved its quality around $34 \%$, using 51 of its current 103 languages, which is a significant number.

Also, Solecki [34] assessed the work of Google Translate in terms of translation of different books from English to Polish and vice versa. He listed some advantages such as: (1) fast translation of long texts, (2) the program can be used to grasp the general meaning, and (3) the application is more accurate than a human when translating some specialized terminology. He listed also some disadvantages: (1) difficulty with complex sentences, (2) use of most common sentence structures without taking into account the meaning, (3) orthography (the appearance of capital letters in the middle of the sentence).

Moreover, it should be stressed that good quality texts have to be always checked by a translator, a human being. Martynenko [24] claims that "post-editing is an obligatory condition for achieving the high quality of online service translations. It is considered the possibility to recognize and allow the application of Google-Translate when teaching a foreign language in a law school". Such a claim is especially important for short texts which were chosen for the analysis, namely contractual clauses.

The aim of the study was an attempt to evaluate the impact of machine translation systems on the translation process, with particular emphasis on translation errors and other language problems. Three typical clauses appearing in contracts as general and three clauses which are typical for copyrights agreements were chosen as

\footnotetext{
${ }^{2}$ Lwowska [23]. Ttumacz z Google z głowq. http://www.lingvika.pl/blog/tlumacz-z-google-z-glowa/). Accessed 06 Aug 2019.
} 
examples of specialist texts characterized by specialized terminology. A very high degree of formulation, and the repeatability of entire sentences is a characteristic feature for typical contractual clauses. The remaining clauses, copyright clauses, are characterized by a low degree of convention, since only single phrases can be treated as common features. The analyzed clauses are authentic clauses from English and Polish contracts, and the conclusions presented below are based on the practical use of automatic translation systems, i.e. Google Translate, for the translation. The conducted analysis shows that one can point some characteristics and conventionalized sentences, so-called "easily translated" sentences/phrases, and on the other hand, errors and language defects occurring in less conventionalized clauses.

\subsection{The Analysis of Typical Clauses for Any Contract ENG-PL}

In some cases, the program automatically generated good translations, which the translator could accept by making corrections only to specialist terminology or changing one of the words/phrases (1) (Umowa publikujaca into Umowa wydawnicza, and praca into utwór or formulaic sentence stanowi co następuje was translated into uzgodniono). To explain why Google Translate was incorrect with its choice let us take the first example of umowa publikujaca, umowa wydawnicza and their features. An umowa wydawnicza, which is the proper term with an English equivalent of publishing agreement, is a legal contract between a publisher and a writer or author (or more than one), to publish written material by the writer(s) or author(s). This may involve a single written work, or a series of works. Such a contract is always made in writing (cf. [15]). In Poland, according to Czachórski [14], every agreement is a mutual contract in which two parties are taking part in and they have mutual understanding toward the establishment, change and pursuit of legal actions. A Publishing Agreement often looks like the contract or license, and includes information about transferring copyrights (property rights) [cf. [4]). Thus, what is an umowa publikujaca? As in English the term is publishing agreement, the Polish version is probably a calque from English. Publikujacy is an adjective in Polish which means publishing or which publishes, hence the translation into umowa publikujaca (literally: a contract which publishes) and not umowa wydawnicza. Moreover, a publishing is a voluntary, bilateral legal document, concluded in writing, on the basis of the relationship arising between an author and a publisher. The author transfers the right to publish his/her work in print or in a similar form. Until 1990, the text of the publishing agreement was permanent in Poland, described in a subsequent regulation of the Council of Ministers or decrees issued by the Minister of Culture and Art [32]. The model agreement established the rights and obligations of publishers and authors, which were as follows:

- the nature, purpose of the work with its title and volume, and delivery date,

- the technical form of the script (at the time the act was created, it was 2-3 copies of a typescript, nowadays about it is more frequently the electronic version of the work),

- the amount and the rules of paying the remuneration, 
- the planned amount of edition,

- the obligation of one correction by the author, subject to the size of the correction,

- deadline for printing,

- the legal and financial guarantees in the event of withdrawal from the contract by the parties (cf. [7]).

The regulation of the Minister of Culture and Art of July 10, 1990 [32] introduced the withdrawal of a model contract. Currently signed contracts are issued on the basis of art. 353 of the Civil Code, taking into account the basic principles in the Act of February 4, 1994 on copyrights and related rights [38]. The essence of each contract is the appropriate definition of its type, i.e. the appropriate heading (cf. [29, 30]). The content and entities to which the contract relates are the key issues. The heading, in a sense, approximates and reflects the initial and general content of the entire contract. The lack of heading (or title) may make it difficult to interpret the contract correctly. There are many different headings when it comes to publishing agreements, and they are related to the nature of the contract (this could be e.g. a license, contract etc.). Usually, such a contract is referred to as a Publishing Agreement in English, and an Umowa Wydawnicza in Polish. From a technical point of view, the heading, i.e. the title of the contract, is usually presented in bold, printed letters, and sometimes the publishing company logo is given next to the title of the contract on letterhead in English publishing contracts and increasingly in Polish.

English-language contracts include a noun in the title: Agreement (Pl. umowa) or Contract (Pl. umowa) and an adjective specifying the subject of the contract in translation into Polish, (in English publishing is a gerundial form-the active participle, which also functions as a noun), e.g. Publishing Agreement. From the grammatical point of view Publishing Agreement is a compound noun consisting of the gerundial form publishing and a noun agreement. Sometimes, in the heading of the contract, there is a specification about the work to be published, e.g. Book Publishing Agreement or Article Publishing Agreement. As it was mentioned earlier, publishing agreements in English are generally referred to as Publishing Agreement in the heading, however, there are also such contracts that do not have a heading and only from the clause regarding the subject of the contract we find out what it is about. Some contracts in English are exemplary. This is a certain contract template that already specifies in the heading what the contract may be about. Then one has to delete those terms that do not belong to the subject of the contract.

In Polish each publishing agreement in its heading contains the genre name "agreement" and a note specifying the subject of the agreement: Publishing agreement (Pl. umowa wydawnicza), License agreement (Pl. umowa licencyjna). In some cases, the contract title is followed by the contract number, e.g. Publishing Agreement No. 10/D/2010 (Pl. Umowa Wydawnicza Nr 10/D/2010), Contract PPC/03/2011/46 (Pl. Umowa PPC/03/2011/46). For greater transparency, contract numbers should be placed for the Publisher. When he/she signs several dozen publishing contracts annually, it is easier to find such a contract by ID number later (PI. numer i seria dowodu osobistego). Usually, the identification number includes the 
month and year of the signing of the contract and additionally the number of the contract signed by the Publisher counting from No. 1 from the beginning of the year (i.e. from the date of signing the first contract in a given year).

To sum up, in comparable texts on publishing agreements, the term Umowa wydawnicza is functionally equivalent to the term Publishing Agreement.

Usually the subject of the publishing agreement is a work, i.e. a manifestation of creative activity of an individual nature established in some way. It can be of a different form or type. In publishing agreements, they can be all kinds of book publications, but also multimedia materials attached to the books (e.g. music, graphics, photographic). What is extremely important is that the words associated with the term "work" vary in terminology. Although the "work" itself is identical in both variants of language (British and American) (cf. [11, 12]), all its divisions and distinctions into other categories will be significantly different. For example, "photographic works" in British are "photograph" (belongs to the artistic works; [2]), while in American this is a "work of visual art" (i.e. drawing, painting, sculpture, which appear in one copy [10], these works do not include posters, maps, tables, diagrams, etc.), in some cases we can find "photographs" because if they are photos that are taken for the exhibition, they could be included into works of visual art [10]. In Legal English, based on the copyright law and related rights, the word work means 'dzieło'/'utwór', and in colloquial language it is 'praca' or 'pracować' (physical work).

The next erroneous translation stanowi co następuje (the following is agreed/witnesseth as follows) was translated into uzgodniono (lit. it was agreed). The idiomatic translation requires the usage of a formulaic sentence, deeply rooted in the Polish legal language.

In the next example (2) is dated was translated literally into Polish as "jest datowana" which in terms of contracts should be translated into "zawarta dnia...".

The comparison (the introduction of the contract) in Polish contracts is usually expressed by an elliptical sentence that begins with the noun umowa (En. contract). It is an inanimate noun, belonging to the female hard-themed declension. It is followed by the passive adjectival participle "contained" in the feminine form in the third person singular. Then, it follows the date of the contract. The date in the title of Polish contracts is formulated by means of a numeral indication of the day, preceded by the expression zawarta $w$ dniu... (En. concluded on...). The month and year are also recorded in numeral form as a rule, although there are exceptions, where the month is written in words.

Both examples (1) and (2) were taken from introduction of contracts. In some cases, it was necessary to correct entire sentences (4), which significantly increased the time needed to perform the translation correction. It was also very strange to discover, as such sentences are very formulaic and appear in every contract. Among the analyzed translations of specialist texts, most sentences have been translated comprehensibly. However, some of them contained factual or grammatical errors that made it difficult to understand the content (1), (3). 


\begin{tabular}{|c|c|c|c|}
\hline e.g. & Source text & Google Translate & Proper translation \\
\hline (1) & $\begin{array}{l}\text { PUBLISHING AGREEMENT } \\
\text { Between Mr X, (hereafter referred to as } \\
\text { Author) and XYZ, (hereafter referred } \\
\text { to as Publisher), concerning the work } \\
\text { entitled ................ (working title; } \\
\text { hereinafter referred to as work) the } \\
\text { following is agreed: }\end{array}$ & $\begin{array}{l}\text { UMOWA PUBLIKUJACA } \\
\text { Pomiędzy panem X (zwanym dalej } \\
\text { „Autorem”) a XYZ (zwanym dalej } \\
\text { „Wydawca”), dotyczacym pracy } \\
\text { zatytułowanej ................. (tytuł } \\
\text { roboczy; zwany dalej ,praca”) } \\
\text { uzgodniono: }\end{array}$ & $\begin{array}{l}\text { UMOWA WYDAWNICZA } \\
\text { Pomiędzy Panem X, (dalej zwanym } \\
\text { „Autorem”) i XYZ, (dalej zwanym } \\
\text { „Wydawca”), dotyczącą utworu pt. } \\
\text {............................. (tytuł rob- } \\
\text { oczy; dalej zwanego „Utworem”) } \\
\text { stanowi co następuje: }\end{array}$ \\
\hline (2) & $\begin{array}{l}\text { This Agreement is dated the 30th April } \\
\text { of } 2004 \\
\text { BETWEEN: XYZ Publishing House } \\
\text { AND: X and Y ('You') whose regis- } \\
\text { tered address is (the Publisher) }\end{array}$ & $\begin{array}{l}\text { Niniejsza Umowa jest datowana na } 30 \\
\text { kwietnia } 2004 \text { r } \\
\text { POMIEDZY: Wydawnictwo XYZ } \\
\text { ORAZ: X i Y (,Ty"), których } \\
\text { zarejestrowanym adresem jest } \\
\text { (Wydawca) }\end{array}$ & $\begin{array}{l}\text { Umowa zawarta } 30.04 .2004 \text { roku } \\
\text { pomiędzy: XYZ Publishing House } \\
\text { i X i Y ('Strony'), których adres jest } \\
\text { następujący: (Wydawca) }\end{array}$ \\
\hline (3) & $\begin{array}{l}\text { The remuneration shall be payable } \\
\text { based on a correctly issued bill } \\
\text { provided to the Contracting Party by } \\
\text { transfer to the bank account indicated } \\
\text { in the bill }\end{array}$ & $\begin{array}{l}\text { Wynagrodzenie płatne jest na podstawie } \\
\text { prawidłowo wystawionego rachunku } \\
\text { przekazanego Umawiajacej sie } \\
\text { Stronie poprzez przelew na rachunek } \\
\text { bankowy wskazany w rachunku }\end{array}$ & $\begin{array}{l}\text { Wynagrodzenie płatne będzie na } \\
\text { podstawie prawidłowo wystawionego } \\
\text { rachunku dostarczonego przez Stronę } \\
\text { przelewem na konto wskazane w } \\
\text { rachunku }\end{array}$ \\
\hline (4) & $\begin{array}{l}\text { This Agreement has been executed and } \\
\text { signed by two parties in duplicate. } \\
\text { All changes and additional agree- } \\
\text { ments will be null and void unless } \\
\text { confirmed in writing }\end{array}$ & $\begin{array}{l}\text { Niniejsza umowa została wykonana } \\
\text { i podpisana przez dwie strony w } \\
\text { dwóch egzemplarzach. Wszelkie } \\
\text { zmiany i dodatkowe umowy będa } \\
\text { nieważne, chyba że zostana potwierd- } \\
\text { zone na piśmie }\end{array}$ & $\begin{array}{l}\text { Niniejsza umowa została } \\
\text { sporządzona i podpisana } \\
\text { przez obie strony w dwóch } \\
\text { jednobrzmiących egzemplarzach. } \\
\text { Wszelkie zmiany do umowy pow- } \\
\text { inny być sporządzone na piśmie } \\
\text { pod rygorem nieważności }\end{array}$ \\
\hline
\end{tabular}

Moreover, in the example (1) Google Translate is inconsistent. It changes capital letters into lower case letters and vice versa. In Poland, it is assumed that polite phrases such as $\mathrm{Mr} / \mathrm{Mrs}$ are written with capital letters. However, in the example (2), the application left capital letters as in the original version of the clause, that is BETWEEN/POMIĘDZY, AND/ORAZ, which when translated by a human translator were changed into small letters, as it is more common practice. Apart from that, after the date there is an abbreviation "r" without a corresponding full stop. It is not known why Google Translate translated the date 30th April 2004 into 30 kwietnia $2004 \mathrm{r}$ without a full stop. It is also cumbersome when it comes to the translation of the proper noun 'you' into 'ty' in a contract. It should be translated as a "Party" to the contract, in Polish "Strona", implicitly "Strona Umowy".

The comparison (the introduction of a contract) is the technical introduction of the contract. It includes elements such as the date of the contract and the parties to the contract. The parties' designation, date and place of concluding the contract are usually below the contract heading. Parties' designations can be introduced in various ways. In English, this is often represented by the phrase Parties of the Agreement. In Polish, however, the contract begins with the designation of the parties without a heading.

In English contracts, in this part of the contract we specify the parties of the contract and give them "a new name" or "a new function". This function, the so-called "determinant" of the contracting party, is given using the archaic adverb hereinafter/ hereafter (referred to/called) (hereinafter referred to as). Thanks to this operation, the full names of the publishers or the author's name and surname are shortened to the functional names of the Publisher-Author type. Also, when discussing the spelling of terms that define the parties to a contract, e.g. author, publisher, or the term 
contract itself, the letters are capital in English, while in Polish we usually use lowercase letters. As for the designation of the parties, it is at the beginning of the Polish document just after the date of the contract. In Polish contracts, parties that are natural persons are determined not only by their last name, first name, address, but also by their ID number or PESEL number (personal identification number). However, if the party is not a natural person but a legal person or business entity, the company name, registered office, REGON number (business registration number), etc. should be provided. It should be noted that the texts of Polish contracts replace all personal data with abbreviated names, which are nouns referring to the class of things (Agency, Publisher) or terms resulting from the type of contract, showing the obligatory relationship: Author, Creator, Buyer. Both parties in the contract are determined by the function assigned to them in the contract. This function, as we can see from the example above, is introduced by means of a fixed formula: "hereinafter" (Pl. zwany dalej), "hereinafter referred to as in the further part of the contract" (Pl. zwanym w dalszej części umowy) and as a result they are already determined by this function. The consequence of this is that the verb subsequently takes the form of a third person singular or plural, e.g. has (right), undertakes, declares, etc. Most often, the parties' names are usually referred to as: autor (En. Author), twórca (En. Creator), and the other party is wydawca (En. Publisher).

Depending on the function performed by the parties of a contract, additional names defining them are in legal language in acts: twórca (creator), współtwórca (co-creator), autor (author), właściciel praw do utworu (rights holder), producent (producer), użytkownik (user), wydawca (publisher), kompozytor (composer), etc. (these terms appear in the Act) or only in legal language in e.g. contracts: artysta (artist), wykonawca (performer), etc. Depending on the type of a work, the name of the party may vary, e.g. a lute can be created by a creator, performer, author or luthier. It depends on what is the subject of the contract and how the parties define their functions in the contract. To sum up, some names of the parties such as Zamawiajacy (Ordering Party) - Wykonawca (Contractor) are nomen agentis nouns, i.e. those that specify the performer of a given activity. In Polish these types of nouns are formed by the suffixes -ący and -ca.

In the example (3), the party to the contract was translated as "Umawiająca się Strona" (en. Contracting Party) which sounds awkward, but the message is conveyed. As an unsaid rule, it is translated simply into "Strona" (en. Party). Also, the usage of the word provided into "przekazanego" (lit. trans. transferred) instead of "dostarczonego" (lit. trans. delivered) is similar in character to the literal translation as "parties" to the contract. In the example (4), the typical verb for contracts, namely "to execute", was translated literally into "wykonać", which does not sound suitable in the context of language of contracts. In such case we use verb "sporządzić".

\subsection{The Analysis of Typical Clauses for Copyright Contracts ENG-PL}

In the case of clauses typical for copyright transfer agreements, in the first example (1), besides the erroneous translation of the term "work" in general, the translation 
is acceptable in its entirety. It is only puzzling that the translation of the term "Publisher" was translated into "Wydawcym" which is a clear spelling mistake with the last added " $m$ " to the word (it should by "Wydawcy", that is Publisher). In example (2), there are a lot of factual errors. Even so, the grammar of the sentences is correct. A very similar case is in example (3).

\begin{tabular}{|c|c|c|c|}
\hline e.g. & Source text & Google Translate & Proper translation \\
\hline (1) & $\begin{array}{l}\text { AUTHOR is the composer/ } \\
\text { lyric writer/arranger of the } \\
\text { work titled } \\
\text { the works described in Annex } \\
\text { A, hereafter referred to as the } \\
\text { "Work". AUTHOR shall remit } \\
\text { the Work to PUBLISHER before } \\
\text { (delivery date) in } \\
\text { the form of: - a sound carrier - a } \\
\text { manuscript. }\end{array}$ & 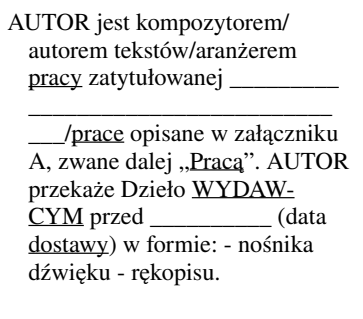 & $\begin{array}{l}\text { AUTOR jest kompozytorem/ } \\
\text { autorem tekstów piosenek/ } \\
\text { aranżerem utworu o nazwie } \\
\text { opisany jest w załączniku A, } \\
\text { i w dalszej części umowy jest } \\
\text { zwany „Utworem”. AUTOR ma } \\
\text { przesłać Utwór WYDAWCY przed } \\
\text { (data dostarczenia } \\
\text { utworu) w postaci: - nośnika } \\
\text { dźwięku - manuskryptu. }\end{array}$ \\
\hline (2) & $\begin{array}{l}\text { No royalty shall be paid on copies } \\
\text { sold at a remainder price (any } \\
\text { sale at or below manufacturing } \\
\text { cost being deemed a remainder } \\
\text { sale) or on copies furnished } \\
\text { without charge for review, } \\
\text { advertising, sample, promotion } \\
\text { or other similar purposes, or on } \\
\text { damaged copies. }\end{array}$ & $\begin{array}{l}\text { Nie należy uiszczać opłat } \\
\text { licencyjnych za sprzedane } \\
\text { egzemplarze po cenie pozostałej } \\
\text { (każda sprzedaż po lub poniżej } \\
\text { kosztów produkcji uważana jest } \\
\text { za pozostała sprzedaż) lub na } \\
\text { kopiach dostarczonych bez opłat } \\
\text { za przegladd, reklamę, próbkę, } \\
\text { promocję lub inne podobne cele, } \\
\text { lub na uszkodzone kopie. }\end{array}$ & $\begin{array}{l}\text { Tantiemy nie zostaną wypłacone za } \\
\text { przecenione egzemplarze (dotyczy } \\
\text { to każdej sprzedaży w cenie kosztu } \\
\text { wytworzenia lub poniżej takiego } \\
\text { kosztu) lub za egzemplarze przeka- } \\
\text { zane bezpłatnie w celu uzyskania } \\
\text { recenzji, reklamy, próbki, promocji } \\
\text { lub innych podobnych celów, a } \\
\text { także za uszkodzone egzemplarze. }\end{array}$ \\
\hline (3) & $\begin{array}{l}\text { This Agreement shall be subject } \\
\text { to termination at the election } \\
\text { of Licensor, in the event that } \\
\text { Licensee fails to begin distribut- } \\
\text { ing Work within one (1) year } \\
\text { of the date on which all parties } \\
\text { have signed this Agreement, by } \\
\text { written notice given by Licensor } \\
\text { to Licensee within thirty (30) } \\
\text { days of the running of that one } \\
\text { (1) year period. }\end{array}$ & $\begin{array}{l}\text { Niniejsza Umowa podlega } \\
\text { rozwiazaniu w momencie } \\
\text { wyboru Licencjodawcy, w } \\
\text { przypadku gdy Licencjobiorca } \\
\text { nie rozpocznie dystrybucji Pracy } \\
\text { w ciagu jednego (1) roku od daty } \\
\text { podpisania niniejszej Umowy } \\
\text { przez wszystkie strony, w drodze } \\
\text { pisemnego zawiadomienia prze- } \\
\text { kazanego przez Licencjodawcę } \\
\text { Licencjobiorcy w ciagu trzy- } \\
\text { dziestu (30) dni od upływu tego } \\
\text { jednego (1) okresu. }\end{array}$ & $\begin{array}{l}\text { Licencjodawca może rozwiązać } \\
\text { niniejszą umowę w wypadku gdy } \\
\text { Licencjobiorca nie rozpocznie } \\
\text { rozpowszechniania Utworu w } \\
\text { ciagu jednego (1) roku od daty } \\
\text { podpisania Umowy przez Strony w } \\
\text { drodze pisemnego zawiadomienia } \\
\text { przekazanego przez Licencjodawcę } \\
\text { Li-cencjobiorcy w ciagu trzy- } \\
\text { dziestu (30) dni od upływu tego } \\
\text { jedno-rocznego okresu. }\end{array}$ \\
\hline
\end{tabular}

In example (2), the terminology is the main drawback. Google Translate translated such terms as "remainder price", "copies" literally into "pozostała sprzedaż", "kopie" instead of consequently "przecenione egzemplarze", "egzemplarze". Also, the term "royalty" was translated inexpertly into "opłaty" instead of "tantiemy".

It is also puzzling how grammar/style looks like in the brackets "po lub poniżej kosztów" instead of "w cenie lub poniżej". The rest of the sentence remains incomprehensible "na kopiach dostarczonych bez opłat za przegląd" and requires a translator's total intervention.

In example (3) the beginning of a sentence is an incorrect translation. Google Translate does not cope with more complex sentences. Once again, it does not collate with the specialised terminology of contracts; the term "work" translates as "praca" (lit. physical work, any type of work, job), instead of "utwór", which is a 
work of art and a work in the meaning of copyrights. Also, the application does not translate "(1) year period" as "roczny okres" but "(1) jeden okres" (lit. one period) which is an obviously incorrect translation.

\subsection{The Analysis of Typical Clauses for Any Contract PL-ENG}

In the case of contracts translated from Polish into English in the first example (1), the program cannot deal with the change of punctuation, date transformation and heading (2) and some of the names (3).

\begin{tabular}{|c|c|c|c|}
\hline e.g. & Source text & Google Translate & Proper translation \\
\hline (1) & $\begin{array}{l}\text { [Umowa] zawarta w dniu } \\
28.02 .2013 \text { pomiędzy .......... } \\
\text { a .......... }\end{array}$ & $\begin{array}{l}\text { [Agreement] concluded on Febru- } \\
\text { ary } 28,2013 \text { between........... } \\
\text { And } . . . . . . .\end{array}$ & $\begin{array}{l}\text { [Contract] made on this } 28 \text { th day of } \\
\text { February } 2003 \text { between ....... and } \\
\ldots \ldots \ldots\end{array}$ \\
\hline (2) & $\begin{array}{l}\text { UMOWA WYDAWNICZA } \\
\text { Z AUTOREM UTWORU } \\
\text { ORYGINALNEGO, WYBORU } \\
\text { LUB OPRACOWANIA zawarta } \\
\text { w dniu 05.12.2000 w Łodzi } \\
\text { pomiędzy Wydawnictwem XYZ } \\
\text { zwanym w dalszym ciągu tej } \\
\text { umowy „Wydawca”, w imieniu } \\
\text { którego działa Y i Panem/ią X } \\
\text { zamieszkałym/ą w Warszawie, ul. } \\
\text { Słoneczna 18, 00-001 Warszawa } \\
\text { zwanym/ą w dalszym ciągu tej }\end{array}$ & $\begin{array}{l}\text { AGREEMENT IS PUBLISHING } \\
\text { WITH ORIGINAL ORIGINAL } \\
\text { AUTHORITY, SELECTION OR } \\
\text { DEVELOPMENT concluded } \\
\text { on } 05.12 .2000 \text { in Łódź between } \\
\text { XYZ Publishing House, which is } \\
\text { still the subject of this contract, } \\
\text { the "Publisher" on behalf of } \\
\text { which Y i Panem X is resident } \\
\text { in Warsaw, ul. Słoneczna 18, } \\
\text { 00-001 Warszawa, also referred } \\
\text { to as the "Author". }\end{array}$ & $\begin{array}{l}\text { PUBLISHING AGREEMENT } \\
\text { WITH THE AUTHOR OF AN } \\
\text { ORIGINAL WORK, COLLEC- } \\
\text { TION OR COMPILATION made } \\
\text { on 5th day of December } 2000 \text { in } \\
\text { Łódź, by and between the XYZ } \\
\text { University hereinafter called "the } \\
\text { Publisher", represented by Y and X } \\
\text { residing in Warsaw, ul. Słoneczna } \\
\text { 18, 00-001 Warszawa, hereinafter } \\
\text { called "the Author". }\end{array}$ \\
\hline
\end{tabular}

(3) Strony ustalają, że z tytułu sporządzenia Utworu i przeniesienia autorskich praw majątkowych do Utworu na wszystkich polach eksploatacji wskazanych w niniejszym paragrafie oraz przeniesienia prawa do zezwalania na rozporządzanie i korzystanie z opracowań Utworu Nabywca zapłaci Twórcy wynagrodzenie w wysokości... zł. Wynagrodzenie to wyczerpuje w całości roszczenia pieniężne Twórcy z tytułu zawarcia niniejszej Umowy.

4. Wynagrodzenie, o którym mowa w ust. 3 zostanie uiszczone w terminie... dni od zawarcia niniejszej Umowy przelewem na wskazany niżej rachunek bankowy Twórcy: [dane rachunku bankowego]

(4) Umowę sporządzono w trzech jednobrzmiących egzemplarzach, po jednym dla Autorów i Wydawcy

The parties agree that due to the creation and transfer of copyright to copyrights and the transfer of the right to authorize changes... PLN. The remuneration to be fully exhausted with the Creator's monetary claims due to the conclusion of this contract. 4 . The remuneration referred to in para. 3 shall be paid within... days from the conclusion of this contract. Transfer to indicate the bank account of the Author: [bank account details]
The Parties agree that for the execution of the Work and the transfer of the economic rights to the Work in all fields of exploitation indicated in this paragraph and transfer of the right to dispose and use the compilations of the Work, the Buyer shall pay the Author a fee of PLN.... The fee hereunder fully covers the Author's pecuniary claims.

4. The fee referred in paragraph 3 shall be paid within... days from the conclusion hereof by transfer into the following bank account of the Author:

[bank account details]
The contract was drawn up in three identical copies, one for the Authors and the Publisher
This Agreement has been executed in triplicate, one copy for each party the Authors and the Publisher

Examples (1) and (2) were taken from the introduction of a contract. Essentially, example (1) could be accepted in its entirety, however, it is puzzling how the Polish 
conjunction "a" (in a word and) after the comma in English is written with a capital letter.

In example (2) at the beginning, the contract heading is completely incomprehensible and needs to be translated again. The words are repeated, the terminology is non-specialist. Also, the program does not consistently translate dates. In this case, we have a Polish date record, identical to the original. The part of the sentence concerning the other party to the contract also needs to be corrected because it is grammatically incorrect. The program also did not translate the word "Pan/Pani" into English (lit. Mr/Ms), leaving it in the original and omitting the female version of the word, "Pani" (lit. Ms).

In example (3) the first sentence is translated only in part. The program omits the essential content that the original contains. The terminology used also requires correction, e.g. "wyczerpywać" translated into "exhaust" instead of "cover", "roszczenia pieniężne" into "monetary claims" instead of "pecuniary claims". We have to take into account the meaning of the Polish word "wyczerpywać". Polish Dictionary (SJP) provides four different meanings. The first one references drawing something, e.g. removing liquid or a loose material with something until the container is empty. The second one is about using or exploiting something. The third meaning is causing the loss of physical and mental strength. The last meaning concerns something which was said to which nothing more can be added as the topic was dealt with in its entirety. The word roszczenie (lit. claim) in civil law, is the right to demand from a designated person to behave in a certain way. While pieniężny means literally: monetary, financial, of money, pecuniary, moneyed; in legal language + claim $=$ pecuniary claim.

It is difficult for Google Translate to find and translate fossilized and archaic structures like "hereof", "hereafter" etc. They are translated as "of this contract", "to this contract" etc. In this example, we also have grammatical defects such as "referred to in" or "transfer to indicate" (cf. [3]). Generally, example (4) can be accepted in its entirety without corrections.

\subsection{The Analysis of Typical Clauses for Copyright Contracts PL-ENG}

Below in the table there are some examples of clauses taken from Polish contracts and translated by Google Translate. Below the table are comments concerning the translation.

\begin{tabular}{|c|c|c|c|}
\hline e.g. & Source text & Google Translate & Proper translation \\
\hline (1) & $\begin{array}{l}\text { Przedmiotem umowy jest } \\
\text { przeniesienie autorskich praw } \\
\text { majątkowych do projektu logo } \\
\text { przedstawionego w załączniku } \\
\text { nr } 1 \text { do Umowy, zwanego dalej } \\
\text { „Utworem” }\end{array}$ & $\begin{array}{l}\text { The subject matter of the contract } \\
\text { is the transfer of the proprietary } \\
\text { copyrights to the logo project } \\
\text { presented in Annex No. } 1 \text { to the } \\
\text { Agreement, hereinafter referred } \\
\text { to as the "Work" }\end{array}$ & $\begin{array}{l}\text { The object of the contract is the trans- } \\
\text { fer of the economic rights to the } \\
\text { project of a logo which is presented } \\
\text { in schedule } 1 \text { hereto, hereinafter } \\
\text { called "the Work" }\end{array}$ \\
\hline
\end{tabular}


Proper translation

(2) Z tytułu wykonania niniejszej umowy, Zamawiający wypłaci Wykonawcy wynagrodzenie ryczaltowe $w$ wysokości (słownie:

złotych, po-mniejszone o należne obciążenia publicznoprawne wynikające $z$ obowiązujących przepisów prawa

(3) Czas trwania umowy

a. Umowa wchodzi w życie z dniem jej podpisania

b. Umowa zawarta jest na czas oznaczony do zakończenia Akcji Marketingowej, nie dłużej jednak niż do dnia... r. chyba, że na pod-stawie pisemnych ustaleń pomiędzy stronami, przesunięciu ulegnie termin zakończenia działań na polach namiotowych i kempingowych, i wraz z tym zmianie ulegnie harmonogram prac

c. Strony są uprawnione do rozwiązania Umowy ze skutkiem na-tychmiastowym w przypadku niewykonania lub nienależytego wy-konania przez drugą ze Stron zobowiązań wynikających z Umowy, mimo uprzedniego wezwania do wykonania Umowy zgodnie z jej treścią, po bezskutecznym upływie terminu w nim określonym, nie krótszym niż 7 dni

d. Strony są uprawnione do wypowiedzenia Umowy w każdym cza-sie, na piśmie pod rygorem nieważności, z zachowaniem 30 dnio-wego okresu wypowiedzenia

e. W przypadku wygaśnięcia lub rozwiązania Umowy przed datą określoną w $\S 8$ ust. 2 Umowy, z przyczyn zawinionych przez któ-rąkolwiek ze Stron, będzie ona zobowiązana do zapłaty na rzecz drugiej Strony wszystkich poniesionych przez tę Stronę i należycie udokumentowanych kosztów zgodnie z postanowieniami Umowy

f. Wygaśnięcie lub rozwiązanie umowy nie niweczy skuteczności postanowień $\S 5 \mathrm{w}$ zakresie, w jakim dotyczyć one będą Dzieł, do których prawa zostaną przeniesione przed wygaśnięciem czy sku-tecznym rozwiązaniem Umowy

Consent to perform work in the
amount of__in words:

zlotys, minority interest payments due to public law legal result

Duration of the contract

a. The contract shall enter into force on the day of its signature

b. The contract is concluded for a definite period of time until the end of the Marketing Action, but no longer than by... unless, on the basis of written arrangements between the parties, the date of completion of activities on the camping and camping fields will be postponed, and this will change the work schedule

c. The Parties are entitled to terminate the Agreement with immediate effect in the event of non-performance or improper performance by the other Party of obligations under the Agreement, despite prior call for performance of the Agreement in accordance with its content, after the expiration of the period specified therein, shorter than 7 days

d. The Parties are entitled to terminate the Agreement at any time in writing under pain of nullity, with a 30 -day notice period.

e. In the event of expiration or termination of the Contract prior to the date specified in $\$ 8$ subpara. 2 of the Agreement, for reasons attributable to any of the Parties, it will be obliged to pay to the other Party all incurred by this Party and duly documented costs in accordance with the provisions of the Agreement

f. Termination or termination of the contract does not invalidate the effectiveness of the provisions of $\S 5$ to the extent to which they will concern the Works to which the rights will be transferred before the expiration or effective termination of the Agreement
The Ordering Party shall pay the

Contractor a flat-rate remuneration in the amount of

PLN (in words: PLN),

deducted by due public and legal taxes and levies resulting from applicable law

Duration of the contract

a. The contract shall enter into force on the day of its signing

b. The contract shall be concluded for a definite time until the end of the Marketing Action, but no longer than until... unless, on the basis of written arrangements between the parties, the date of completion of activities on the camping fields shall be postponed, and with this change the work schedule shall follow

c. The Parties are entitled to terminate the Agreement with immediate effect in the event of failure to perform or improper performance of the obligations under the Agreement by the other Party, despite prior call for performance hereof in accordance with its content, after ineffective expiration of the period specified therein not shorter than 7 days

d. The Parties are entitled to terminate the Agreement at any time in writing, on pain of nullity, with 30 days' notice.

e. In the event of expiry or termination hereof prior to the date specified in para. 8.2 hereof for reasons attributable to any of the Parties, the Party shall be obliged to pay to the other Party all costs incurred and duly documented by this Party in accordance to the provisions hereof

$f$. The expiration or termination of the Agreement shall not nullify the effectiveness of the provisions of para. 5 to the extent to which they shall concern the Works to which the rights will be transferred before the expiration or effective termination hereof 
"Przedmiot umowy" is in many cases incorrectly translated as "subject matter" as shown in example (1).

Husak [18] with reference to the Copyright Act and the WIPO treaty [36] says that:

'Przedmiot prawa autorskiego'(subject matter of copyright) has finally been translated as 'the subject matter of copyright'. The reason for this decision was the ambiguity of the word 'subject' and the need to narrow down its meaning. The proposal of 'the scope of copyright' was rejected because it is neither about scope nor content. It should be noted, however, that the phrase 'być przedmiotem prawa autorskiego' (be subject to copyright law) is translated as 'to be copyrighted', not as 'to be subject of copyright'.

However, once again, the choice of terminology is unsatisfactory: "prawa majątkowe" is "proprietary copyright" instead of "economic rights". Economic rights are the rights of the author of the work. Economic rights primarily secure economic issues related to work. In Poland, these rights are associated only with financial benefits. In Polish law, the concept of economic rights is regulated by art. 17 of Copyright Act (and further articles). It provides that the creator/author has the exclusive right to use and dispose of the work in all fields of exploitation and to receive remuneration for using the work. There are many phrases in the act with the term 'work'. Therefore, to properly translate legal texts, it is not enough to know the terminology alone, because the phrases appearing in such texts function in "conventionalized phrases and idiomatic expressions" [20].

In English, on the other hand, according to Copyrights, Designs and Patents Act [13] it is property rights. These rights relate to the ownership of the work by a person and the determination by that person how the property can be disposed of. The list of works according to the Act is in art. 1 of the Copyrights, Designs and Patents Act. In the American Copyright Act [37] there is a more specific term, namely [intellectual] property rights, meaning literally 'prawa własności [intelektualnej]'. The American equivalent applies to a broader category of law-intellectual property law, which includes copyright law. This term is a hyperonym for the Polish term. Therefore, this equivalent is partial. In contrast, the British term is more general referring to the possession of things and not to the financial benefits of the work. Therefore, the term can be considered a partial equivalent. It should be noted that "the Polish unified terminology system POLTERM assumes that the term once adopted is used in all legal acts which translation is based on this system" [18]. Therefore, the translation should include existing equivalents that are in use. The term prawa majatkowe (En. economic rights) has its equivalent in English, i.e. the author's economic rights. This term, however, does not appear in British and American acts. Instead, it appears in the World Intellectual Property Organization

\footnotetext{
3 'przedmiot prawa autorskiego' został ostatecznie przetłumaczony jako 'the subject matter of copyright'. Przyczyną takiej decyzji była wieloznaczność słowa 'subject' i konieczność zawężenia jego znaczenia. Propozycja 'the scope of copyright' została odrzucona, ponieważ nie chodzi ani o zakres, ani o treść. Należy jednakże zauważyć, że wyrażenie 'być przedmiotem prawa autorskiego' tłumaczone jest jako 'to be copyrighted', a nie jako 'to be subject of copyright'.
} 
(WIPO) treaty, and Poland, the United States and the United Kingdom have ratified this treaty. According to the definition of the WIPO treaty [35: 96]:

Economic rights - in relation to works, rights of authors forming the pecuniary components of copyright, as distinguished from moral rights. They imply as a rule that within the limitations set by the copyright law the owner of the copyright may make all public use of the work conditional on payment of remuneration. Economic rights comprise in particular, the faculty to do or to authorize the doing of any of the following: to publish or otherwise reproduce the work for public distribution: to communicate it to the public by performance, by broadcasting or by wire: to make translations of any kind of adaptation of the work and to use these in public, etc.

Poland is also a member of WIPO and has signed relevant documents, therefore the Polish term autorskie prawa majatkowe (En. economic rights) and English term author's economic rights should be considered as near equivalents. The American term is a modified equivalent. Property rights is a term meaning prawa majatkowe, but the context, and the scope of the copyright act, including its title, is limited in the meaning. It concerns works of arts, not immovable things (immovable properties). Hence, the context of the term property rights has been narrowed. The interpretation of the meaning of the term property rights depends, therefore, on the context in which it is used and may mean both rights to all types of property or exclusive rights to the work. Thus, how the term is translated from American law will depend on the meaning given to it in a specific text by a specific author. The British term should be interpreted in a similar way.

The other term "załącznik" was translated as "Annex" instead of "schedule". What is załacznik? In the Dictionary of the Polish Language (Słownik Języka Polskiego [33]) we can find two meanings. The first one says that załacznik is a document attached to another document as complementary material. Possible translations are attachment, annex, schedule, but in terms of legal documents it should be translated into schedule. The first term attachement means "a legal process by which a court of law, at the request of a creditor, designates specific property owned by the debtor to be transferred to the creditor, or sold for the benefit of the creditor" (cf. [9]). According to Black's Law Dictionary the term annex means "something that is attached, such as a document to a report or an addition to a building." [17]. And schedule means "a written list or inventory; esp., a statement that is attached to a document and that gives a detailed showing of the matters referred to in the document" [17]. The second meaning of załacznik is completely non-usable in a legal document contract because of its relation to a colloquial term for a bribe. However, the translation of the term "utwór" from Polish to English is correct this time. Also, the program does not use archaic phrases "hereto", "hereafter" etc. from Polish to English.

Example (2) is full of inaccuracies. Substantial information is omitted, a lack of content and grammatical and terminological errors appear.

In example (3) we have a lot of good translation. In a few cases, the text required extensive intervention by the translator. Contracts most often use constructions with the modal verb "shall", e.g. "shall be done" (cf. [5]). In all cases, the program uses 
the verb will or verbs in the present tense. The translation of some ossified structures such as "on pain of nullity" into "under pain of nullity" is also questionable. In English, especially the British variant, the symbol $\S$ is not used. In this case, Google Translate left the symbol in the original. There are also repetitions of the same words, because English likes the use of synonymous strings, which do not appear so often in the legal language of Polish.

\section{Final Results}

The examination carried out by the author into the Polish-English and English-Polish materials corroborates the reported results of the research of other translators in relation to the usefulness of machine translation in the translation of specialist texts. Google Translate generated mostly good translations for clauses. This probably results from the large convention of the analyzed clauses and a rich database of translations used by the Google Translate system.

Many sentences from machine translation can be accepted unchanged or after minor adjustments. However, it would be a mistake to say that the translator needs less time to improve translation of specialist texts in comparison to other types of texts. This is due to the large number of terminological errors in the translation of specialist texts, the correction of which-depending on the language skills and knowledge of the translator-can be time-consuming.

Based on the examples of translations discussed above, it has been shown that Google Translate still produces a few unintelligible sentences, as well as sentences whose significance to a smaller or greater extent changes the meaning of the source text. This proves that currently machine translation systems are still not able to replace human work, but undoubtedly they can significantly accelerate it, because translations are generated in a few to several dozen seconds, and the translator takes over the role of the corrector (post-editor, or-in other words-machine translation editor).

However, one should pay attention to the danger of too much dependence on the equivalents proposed by Google Translate and consequently not having enough due diligence to check their accuracy, especially under time pressure.

Despite numerous translation errors and language defects, the described application can be treated as a valuable workshop assistance/tool. Taking into account the quality of the translations, it can be assumed that Google Translate is useful in the work of a professional translator.

Open Access This article is licensed under a Creative Commons Attribution 4.0 International License, which permits use, sharing, adaptation, distribution and reproduction in any medium or format, as long as you give appropriate credit to the original author(s) and the source, provide a link to the Creative Commons licence, and indicate if changes were made. The images or other third party material in this article are included in the article's Creative Commons licence, unless indicated otherwise in a credit line to the material. If material is not included in the article's Creative Commons licence and your intended use is not permitted by statutory regulation or exceeds the permitted use, you will need to obtain permission directly from the copyright holder. To view a copy of this licence, visit http://creativecommons.org/licen ses/by/4.0/. 


\section{References}

1. Aiken, M. 2019. An updated evaluation of Google Translate accuracy. In Studies in linguistics and literature, 253-260. https://www.researchgate.net/publication/334523114_An_Updated_Evaluation _of_Google_Translate_Accuracy. Accessed 07 Aug 2019.

2. Bainbridge, D., and C. Howell. 2013. Intellectual property law. Harlow: Pearson Education Limited.

3. Bazlik, M., P. Ambrus, and M. Bęcławski. 2010. The grammatical structure of legal English. Warszawa: Translegis.

4. Benton, L., and K.H. Porter. 2013. The publishing agreement. Kindle Edition.

5. Berezowski, L. 2008. Jak czytać i rozumieć angielskie umowy?. Warszawa: C.H. Beck.

6. Biel Ł. 2009. Terminologia polskiego, angielskiego i amerykańskiego prawa spółek: organy spółki. In Lingua Legis t. vol 17, 46-57.

7. Birkenmajer, A. 1971. Encyklopedia wiedzy o ksiażce. Wrocław.

8. Bogucki, Ł. 2009. Tłumaczenie wspomagane komputerowo. Warszawa.

9. Chisholm, H. (ed.). 1911. “Attachment”. Encyclopaedia britannica, 11th ed. Cambridge: Cambridge University Press.

10. Christie, A., and S. Gare. 2014. Blackstone's statutes on intellectual property. Oxford: Oxford University Press.

11. Copyright Act of 1976, United States code title 17-copyrights. https://www.copyright.gov/title17/ title17.pdf. Accessed 03 Jan 2020.

12. Copyright Act, 1956, 4\&5 Eliz. 2 Chapter 74. http://www.wipo.int/edocs/lexdocs/laws/en/gy/gy012 en.pdf. Accessed 03 Jan 2020.

13. Copyright, Designs and Patents Act 1988, Chapter 48. https://www.legislation.gov.uk/ukpga /1988/48. Accessed 03 Jan 2020.

14. Czachórski, W. 2007. Zobowiqzania. Zarys wykładu. Warszawa: Wydawnictwo Prawnicze LexisNexis.

15. Damasiewicz, A. 2008. Umowy wydawnicze. Warszawa: Wydawnictwo Prawnicze LexisNexis.

16. Delisle, J., et al. (eds.). 1999. Translation terminology. Amsterdam/Philadephia: John Benjamins Publishing Company.

17. Garner, B.A. 2004. Black's law dictionary, 8th ed. St. Paul: Thomson West.

18. Husak, H. 1995. Terminologia POLTERM w zakresie polskiego prawa autorskiego. In: Lingua Legis $n r$ 2. Wydawnictwo Translegis.

19. Jabak, O.O. 2019. Assessment of Arabic-English translation produced by Google Translate. In International Journal of Linguistics, Literature and Translation (IJLLT), pp 238-247.

20. Kaczmarek, K. 2011. Lingua Legis w aspekcie translatologicznym węgiersko-polskim i polskowęgierskim. In Comparative legilinguistics, vol. 6, ed. A. Matulewska. Zakład Legilingwistyki UAM: Poznań.

21. Kubacki, A.D., and M. Łomzik. 2019. Systemy przekładu maszynowego w pracy tłumacza języka niemieckiego.

22. Lewandowska-Tomaszczyk, B. (ed.). 2005. Podstawy językoznawstwa komputerowego. Łódź: Wydawnictwo Uniwersytetu Łódzkiego.

23. Lwowska, K. 2016. Tłumacz z Google z głową, http://www.lingvika.pl/blog/tlumacz-z-google-zglowa/. Accessed 22 Jan 2020.

24. Martynenko, I.A. 2018. Google-Translate: practice and prospects of adaptation in a Law University, pp 81-87. https://www.researchgate.net/publication/334960817_GOOGLE-TRANSLATE_PRACT ICE_AND_PROSPECTS_OF_ADAPTATION_IN_A_LAW_UNIVERSITY. Accessed 07 Aug 2019.

25. Matulewska, A. 2010. Teksty paralelne a ustalanie konotatów i denotatów na potrzeby przekładu polsko-angielskiego. In Comparative legilinguistics. International journal for legal communication, vol. 10/2013, ed. J. Bańczerowski and A. Matulewska, 57-70. Poznań: Zakład Graficzny UAM.

26. Matulewska, A. 2019. A presentation: Google translate and translation of Polish legal texts into English during XIV conference legal translation, Court Interpreting and Comparative Legilinguistics, 28-30 June 2019, Poznań.

27. McGuire, N. 2018. How accurate is Google Translate in 2018? Argo Translation. https://www.argot rans.com/blog/accurate-google-translate-2018. Accessed 8 July 2019. 
28. Neubert, A. 1996. Textlinguistics of translation: the textual approach to translation. In Translation horizons beyond the boundaries of translation spectrum. Translation perspectives IX, ed. Gaddis and Rose Marilyn, 87-105. Binghamton: Center for Research in Translation.

29. Radwański, Z., and A. Olejniczak. 2008. Zobowiazania - część ogólna. Warszawa: C. H. Beck.

30. Radwański, Z. 2007. Prawo cywilne - część ogólna. Warszawa: C. H. Beck.

31. Roald, J., and S. Whittaker. 2010. Verbalization in French and Norwegian legislative texts: a contrastive case study. In Legal discourse across languages and cultures, ed. Maurizio Gotti and Christopher Williams, 95-108. Bern: Peter Lang.

32. Rozporządzenie Rady Ministrów lub zarządzeniach Ministra Kultury i Sztuki (M. P. 1990 nr 30 poz. 240). Accessed 03 Jan 2020.

33. Słownik Języka Polskiego. https://sjp.pl/. Accessed 03 Jan 2020.

34. Solecki, B. 2012. Quantitative and qualitative analysis of sample translations produced by Google Translate and human translators. In The translator and the computer, ed. Ł. Grabowski, and T. Piotrowski, 205-219. Wrocław: Wydawnictwo Wyższej Szkoły Filologicznej We Wrocławiu.

35. The World Intellectual Property Organization. 1983. WIPO glossary of terms on the law of copyright and neighboring rights. Geneva: World Intellectual Property Organization.

36. Traktat Światowej Organizacji Własności Intelektualnej o Prawie Autorskim, sporządzony w Genewie dnia 20 grudnia 1996 r. Dz.U. 2005 nr 3 poz. 12. http://prawo.sejm.gov.pl/isap.nsf/downl oad.xsp/WDU20050030012/O/D20050012.pdf. Accessed 03 Jan 2020.

37. US Code, Title 17-COPYRIGHTS, 2010. https://www.law.cornell.edu/uscode/text/17. Accessed 03 Jan 2020.

38. Ustawa z dnia 4 lutego 1994 r. o prawie autorskim i prawach pokrewnych, Dz. U. $1994 \mathrm{Nr} 24$ poz. 83. http://prawo.sejm.gov.pl/isap.nsf/download.xsp/WDU19940240083/U/D19940083Lj.pdf. Accessed 03 Jan 2020.

Publisher's Note Springer Nature remains neutral with regard to jurisdictional claims in published maps and institutional affiliations. 